\title{
APLIKASI SMARTDIET MENGGUNAKAN LOGIKA FUZZY BERBASIS ANDROID
}

\author{
Nurul Nabila Maharani ${ }^{1)}$, Feri Candra ${ }^{2)}$ \\ ${ }^{1}$ Teknik Informatika, Universitas Riau \\ email: nurulnabilam27@gmail.com \\ ${ }^{2}$ Teknik Informatika, Universitas Riau \\ email: feri@eng.unri.ac.id
}

\begin{abstract}
Health is an essential thing in our lives. One of the characteristics of a healthy body is having an ideal body. To get an ideal body, we should regulate our diet or eating pattern to our daily activity. We can find out that our body is ideal or not by using BMI formula. Moreover, we can total our daily calories need by using BMR formula. Both of the formulas actually can be calculated manually, but the methods are not efficient. Also, in those formulas, the calculations are still standard and inflexible. Therefore, this study uses fuzzy logic with Mamdani methods to calculate the body mass index and calorie requirement figures. Using the fuzzy logic can give tolerances to the result so that there are no significant results. This application uses Java language based on Android so that it can be used practically on smartphones. The result shows that BMI and BMR obtained by this application are the accuracy of $89.62 \%$ and the error value of $10.38 \%$.
\end{abstract}

Keywords: Android, BMI, BMR, Fuzzy Logic, Mamdani

\begin{abstract}
Abstrak
Kesehatan merupakan hal yang paling penting dalam kehidupan kita. Salah satu ciri-ciri tubuh yang sehat adalah berat badan yang ideal. Untuk mencapai berat badan yang ideal, kita harus mengatur pola makan sesuai dengan proposional tubuh dan juga sesuai dengan kegiatan seharihari. Untuk mengetahui apakah berat badan sudah ideal atau belum dapat dihitung dengan rumus BMI. Dan untuk mengetahui jumlah kalori yang dibutuhkan untuk mencapai berat badan ideal dapat dihitung dengan rumus BMR. Kedua rumus tersebut sebenarnya dapat dihitung dengan manual, akan tetapi cara tersebut kurang efisien. Dan juga dalam perumusan tersebut perhitungannya masih kaku dan tidak fleksibel. Maka dari itu, pada penelitian ini akan menggunakan perhitungan keidealan berat badan dan angka kebutuhan kalori dengan logika fuzzy metode Mamdani. Menggunakan perhitungan dengan logika fuzzy dapat memberikan toleransi terhadap nilai tersebut sehingga tidak terjadi adanya perubahan nilai yang signifikan. Aplikasi ini akan dirancang dengan bahasa Java dalam bentuk aplikasi Android sehingga dapat digunakan secara praktis di smartphone. Dari hasil penelitian yang diperoleh perhitungan nilai BMI dan BMR dengan nilai akurasi $89.62 \%$ dan nilai error yang dihasilkan $10.38 \%$
\end{abstract}

Keywords: Android, BMI, BMR, Logika Fuzzy, Mamdani

\section{PENDAHULUAN}

Kesehatan adalah hal yang penting dalam kehidupan kita. Salah satu ciri-ciri badan yang sehat adalah berat badan yang ideal. Berat badan yang ideal merupakan berat badan yang dimana tinggi badan seseorang seimbang dengan berat badannya. Tetapi, tidak banyak yang mengetahui apakah berat badan mereka sudah ideal apa belum. Maka, cara untuk mengetahui keseimbangan berat badan dan tinggi badan kita adalah dengan menghitung rumus Body Mass Index atau BMI.

Body Mass Index atau dalam Bahasa Indonesia Indeks Massa Tubuh adalah rumus perbandingan antara berat badan dan tinggi badan orang dewasa yang digunakan untuk mengetahui ke-ideal-an tubuh seseorang. Penggolongsn BMI terdiri dari Underweight, Normal, Overweight dan Obesitas. Untuk menghitung BMI dapat dilakukan dengan membagi berat badan dalam kilogram dan tinggi badan dikuadratkan dalam meter [1]. 
Salah satu cara untuk mendapatkan tubuh yang ideal adalah dengan makan yang teratur sesuai dengan kebutuhan kalori. Maka dari itu, kita harus mengatur semua kalori yang kita makan agar mendapatkan berat badan yang ideal. Perhitungan kalori yang dibutuhkan dapat dihitung dengan rumus Basal Metabolic Rate (BMR) atau dalam Bahasa Indonesia disebut Angka Metabolisme Basal (ABM).

Basal Metabolic Rate (BMR) atau dalam Bahasa Indonesia disebut Angka Metabolisme Basal (ABM) adalah jumlah energi minimal yang dibutuhkan oleh tubuh untuk menjalankan proses pada bagian vital oleh tubuh seperti pernafasan, peredaran darah, dan alat vital lainnya [2]. Beberapa faktor yang membedakan nilai BMR pada setiap orang, diantaranya adalah ukuran tubuh, komposisi tubuh, jenis kelamin, umur dan aktivitas fisik [3].

Pada perhitungan manual BMI dan BMR masih sulit diimplementasikan dan juga tidak fleksibel. Seiring dengan berkembangnya teknologi terutama dalam bidang kecerdasan buatan, salah satunya adalah logika fuzzy. Penggunaan logika fuzzy dapat memberikan toleransi sehingga tidak terjadi adanya perubahan nilai yang signifikan [4]. Aplikasi ini akan dirancang dengan basis Android sehingga memudahkan pengguna karena bisa dapat diakses langsung dengan smartphone yang mempunyai sistem operasi Android.

\section{METODE PENELITIAN}

Tahapan-tahapan yang dilaksanakan dalam penelitian ini adalah sebagai berikut:

a. Studi Literatur, dilakukan dengan cara mempelajari teori-teori yang berkaitan dengan penelitian baik itu metode, objek penelitian, dan hal-hal lainnya melalui buku, jurnal, dan halaman web yang dapat dipercaya.

b. Pengumpulan Data, dengan cara mengumpulkan informasi tentang datadata yang dibutuhkan dalam penelitian yaitu berat badan, tinggi badan, umur, jenis kelamin dan tingkat aktivitas.

c. Implementasi, dengan cara membangun program dan membuat proses kontrol logika fuzzy. Kemudian melakukan pengujian dengan menggunakan data uji. d. Representasi Hasil, dengan cara menjabarkan hasil IMT dan kebutuhan kalori atau BMI dari hasil perhitungan logika fuzzy Mamdani

e. Kesimpulan, yaitu dengan menyimpulkan hasil dari keseluruhan tahap penelitian yang telah dilaksanakan.

Logika fuzzy adalah cabang dari sistem kecerdasan buatan (Artificial Inteligent) yang mengemulasi kemampuan manusia dalam berfikir ke dalam bentuk algoritma yang kemudian dijalankan oleh mesin. Algoritma ini digunakan dalam berbagai aplikasi pemrosesan data yang tidak dapat direpresentasikan dalam bentuk biner. Logika fuzzy menginterpretasikan statemen yang samar menjadi sebuah pengertian yang logis [5].

Dalam penelitian ini digunakan metode Logika Fuzzy Mamdani atau yang biasa disebut metode MIN-MAX yaitu metode logika fuzzy adalah salah satu bentuk dari fuzzy inference sistem yang berfungsi untuk mengambil keputusan dan menarik kesimpulan dalam suatu permasalahan yang tidak pasti [6].

Tahapan dalam logika fuzzy Mamdani terdapat empat tahap yaitu adalah sebagai berikut:

a. Pembentukan Himpunan Fuzzy.

Pada tahapan pertama prosedur logika fuzzy Mamdani ini, hal yang pertama dilakukan adalah pembentukan himpunan fuzzy. himpunan fuzzy atau fuzzy sets merupakan pengelompokkan sesuatu berdasarkan ekspresi bahasa atau linguistik yang dinyatakan dalam fungsi keanggotaan [7].

b. Aplikasi Fungsi Implikasi

Tahapan selanjutnya adalah pengaplikasian fungsi implikasi. Pada metode Mamdani, fungsi implikasi yang digunakan adalah MIN. Secara umum persamaan fungsi implikasi dapat dituliskan dalam bentuk if-then rule yang diberikan [8].

c. Komposisi Aturan

Tahap ketiga dari proses logika fuzzy metode Mamdani adalah komposisi aturan atau biasa disebut dengan fungsi MAX. Pada tahapan ini solusi himpunan fuzzy diperoleh dengan cara mengambil nilai maksimum dari output yang dihasilkan [9]. Fungsi MAX sendiri 
secara umum dapat dituliskan pada persamaan (1) berikut:

$$
\mu s f[X i]=\max (\mu s f[X i], \mu k f[X i])
$$

Keterangan:

$\mu s f[X i]=$ nilai keanggotaan solusi fuzzy sampai aturan ke-i

$\mu k f[X i]=$ nilai keanggotaan konsekuen fuzzy setiap aturan ke-i

d. Defuzzifikasi

Langkah terakhir adalah defuzzifikasi.

Defuzzifikasi merupakan sebuah

bilangan tunggal, yaitu harga variable masukan dan keluarnya adalah derajat keanggotan dalam suatu fuzzy set dalam antecedent, maka masukan dan keluaran defuzzifikasi adalah sebuah set (dalam hal ini fuzzy set hasil agregasi) dan keluarannya adalah sebuah tunggal untuk diisikan ke sebuah variable keluaran FIS [10].

Defuzzifikasi yang digunakan dalam metode Mamdani ini adalah dengan menggunakan metode Centroid (Composite Moment). Pada metode Centroid ini diperoleh dengan cara mengambil titik pusat dari hasil daerah fuzzy yang didapatkan [5]. Secara umum, metode Centroid dapat dituliskan pada Persamaan (2)

$$
\mathrm{Z}_{0}=\frac{\int_{\mathrm{a}}^{\mathrm{b}} \mathrm{Z} \cdot \mu_{(\mathrm{z})} \mathrm{dz}}{\mu_{(\mathrm{z})} \mathrm{dz}}
$$

Keterangan :

$Z_{0}=$ Hasil Defuzzifikasi

$\mu_{(z)}=$ Derajat Keanggotaan Titik

$Z$ = Nilai domain ke-i

\section{HASIL DAN PEMBAHASAN}

Dalam penelitian ini dilakukan 4 tahapan proses hitungan manual perhitungan penentuan nilai BMI dan BMR dengan logika fuzzy metode Mamdani yang telah dijelaskan pada sub-bab Metodologi. Variabel-variabel input yang akan digunakan untuk menghitung BMI adalah berat badan dan tinggi badan. Sedangkan variabel-variabel input yang digunakan untuk menghitung BMR adalah nilai BMI yang didapatkan dari perhitungan sebelumnya, umur, jenis kelamin dan tingkat aktifitas.
Berikut akan diberikan sebuah contoh kasus dengan kriteria variabel sebagai berikut:

$\begin{array}{ll}\text { Berat badan } & : 45 \mathrm{~kg} \\ \text { Tinggi badan } & : 153 \mathrm{~cm} \\ \text { Umur } & : 20 \text { tahun } \\ \text { Jenis Kelamin } & : \text { Laki-laki } \\ \text { Aktifitas } & : 2 \text { kali seminggu }\end{array}$

Pada perhitungan ini akan didahulukan perhitungan penentuan nilai BMI yang kemudian dilanjutkan dengan perhitungan penentuan nilai BMR.

\section{Perhitungan fuzzy penentuan nilai BMI}

a. Penentuan derajat keanggotaan masingmasing himpunan pada variabel (Fuzzifikasi)

Masing-masing variabel diklasifikasikan dengan beberapa himpunan dengan nilai domain yang telah ditentukan. Nilai domain berfungsi untuk menentukan nilai derajat keanggotaan masing-masing himpunan. Tabel himpunan fuzzy variabel berat badan dan tinggi badan dapat dilihat pada Tabel 1 .

Tabel 1. Himpunan Fuzzy Variabel Berat Badan dan Tinggi Badan

\begin{tabular}{|l|l|l|}
\hline Variabel & Himpunan & Domain \\
\hline \multirow{3}{*}{ Berat badan } & Ringan & {$[30,50]$} \\
\cline { 2 - 3 } & Normal & {$[45,60]$} \\
\cline { 2 - 3 } & Berat & {$[55,80]$} \\
\hline \multirow{3}{*}{$\begin{array}{l}\text { Tinggi } \\
\text { badan }\end{array}$} & Rendah & {$[145,155]$} \\
\cline { 2 - 3 } & Normal & {$[150,170]$} \\
\cline { 2 - 3 } & Tinggi & {$[165,185]$} \\
\hline \multirow{4}{*}{ BMI } & Underweight & {$[10,19.9]$} \\
\cline { 2 - 3 } & Normal & {$[17,24.9]$} \\
\cline { 2 - 3 } & Overweight & {$[23,29.9]$} \\
\cline { 2 - 3 } & Obesitas & {$[28,35]$} \\
\hline
\end{tabular}

a. Variabel berat badan

Untuk nilai variabel berat badan yang diketahui adalah 45 . Variabel berat badan ada 3 himpunan yaitu RINGAN, SEDANG, dan BERAT. Masing-masing himpunan akan dihitung derajat keanggotaannya sesuai 
dengan nilai yang ditentukan. Berikut adalah perhitungan derajat keanggotaan pada himpunan RINGAN pada persamaan 2.

$$
\mu \operatorname{Ringan~}(45)=\frac{(50-45)}{(50-30)}=\frac{5}{20}=0.25
$$

Untuk himpunan NORMAL dan BERAT tidak perlu dihitung derajat keanggotaannya karena nilai variabel yang diketahui tidak memotong grafik himpunan tersebut atau tidak termasuk pada nilai domainnya. Maka nilai derajat keanggotaan untuk variabel 45 pada semua himpunan adalah sebagai berikut:

$$
\begin{gathered}
\mu \text { Ringan }(45)=0.25 \\
\mu \text { Normal }(45)=0 \\
\mu \text { Berat }(45)=0
\end{gathered}
$$

b. Variabel tinggi badan

Nilai variabel berat badan yang diketahui adalah 153. variabel tinggi badan terdapat 3 himpunan fuzzy yaitu RENDAH, NORMAL dan TINGGI. Masing-masing himpunan akan dihitung derajat keanggotaannya sesuai dengan nilai yang ditentukan. Berikut adalah perhitungan derajat keanggotaan pada himpunan RENDAH pada persamaan 3.

$$
\mu \operatorname{Rendah}[153]=\frac{(155-153)}{(155-145)}=\frac{2}{10}=0.2(3)
$$

Hasil dari perhitungan tersebut menunjukan bahwa nilai derajat keanggotaan himpunan RENDAH pada nilai variabel 153 adalah 0.2 selanjutnya adalah himpunan NORMAL. Berikut adalah perhitungan derajat keanggotaan pada himpunan NORMAL pada persamaan 4.

$$
\mu \operatorname{Normal}(153)=\frac{(153-150)}{(163-150)}=\frac{3}{13}=0.23
$$

Untuk himpunan TINGGI tidak perlu dihitung derajat keanggotaannya karena nilai variabel yang diketahui tidak memotong grafik himpunan tersebut atau tidak termasuk pada nilai domainnya. Maka nilai derajat keanggotaan pada semua himpunan adalah sebagai berikut:

$$
\begin{gathered}
\mu \text { Rendah }(153)=0.2 \\
\mu \operatorname{Normal}(153)=0.23 \\
\mu \text { Ting gi }(153)=0
\end{gathered}
$$

b. Penentuan nilai aplikasi fungsi implikasi Setelah semua variabel telah ditentukan derajat keanggotaan pada setiap himpunannya, maka langkah selanjutnya adalah pengaplikasian fungsi implikasi. Fungsi implikasi yang digunakan dalam proses ini adalah fungsi MIN, yaitu dengan mengambil derajat keanggotaan paling sedikit. Berdasarkan aturan-aturan yang sesuai dengan fungsi implikasi yaitu ada 9 aturan tetapi yang digunakan yaitu dua aturan yaitu:

[R1] IF berat badan $=$ RINGAN AND tinggi badan $=$ RENDAH THEN bmi $=$ NORMAL.

$\alpha$-predikat $1=\mu$ BBRingan $\cap$ TBRendah

$=\min (\mu$ BBRingan $(45)$, TBRendah(153))

$=\min f_{0} \cdot(0.25 ; 0.2)$

$=0.2$

[R2] IF berat badan = RINGAN AND tinggi badan $=$ NORMAL THEN bmi $=$ NORMAL.

$\alpha$-predikat $2=\mu$ BBRingan $\cap$ TBNormal

$=\min (\mu$ BBRingan(45),TBRendah(153))

$=\min \left[f_{0}\right)(0.25 ; 0.23)$

$=0.23$

c. Komposisi aturan

Komposisi aturan menggunakan fungsi MAX, sehingga pada metode ini solusi himpunan fuzzy diperoleh dengan cara mengambil nilai maksimum aturan, kemudian menggunakannya untuk memodifikasi daerah fuzzy. Berikut adalah perhitungan dari fungsi MAX pada persamaan 5 .

$$
\begin{aligned}
\mu s f(x)= & \operatorname{maks}\{(\mu \text { bmiNormal }(0.23), \\
& \mu b \operatorname{miNormal}(0.25)\} \\
= & \operatorname{maks}(0.23 ; 0.2)=0.23
\end{aligned}
$$

Karena kedua nilai maksimum berada pada himpunan fuzzy yang sama yaitu himpunan fuzzy bmi NORMAL, maka himpunan yang akan dihitung adalah himpunan NORMAL. Berikut adalah grafik 
himpunan NORMAL untuk menghitung komposisi aturan pada Gambar 1.

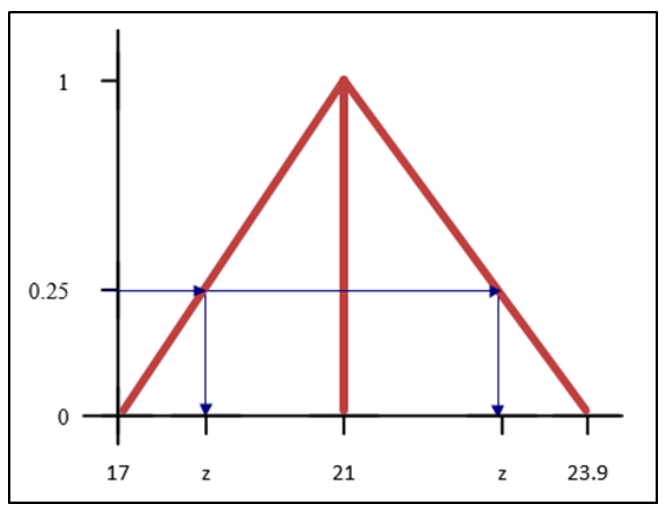

Gambar 1. Grafik Variabel BMI Himpunan Normal pada Komposisi Aturan

Berdasarkan gambar diatas, nilai z dapat ditentukan sebagai berikut:

$$
\begin{aligned}
& 0.23=\frac{z-17}{4} \\
& 0.92=z-17 \\
& z=17.92 \\
& \quad \text { atau } \\
& 0.23=\frac{24.9-z}{3.9} \\
& 0.897=24.9-z \\
& z=24.003
\end{aligned}
$$

Maka, fungsi keanggotaan untuk hasil komposisi ini adalah:

$$
\mu(z)=\left\{\begin{array}{c}
0, z<17 \\
\frac{z-17}{4} ; 17 \leq z \leq 17.92 \\
0.25 ; 17.92 \leq z \leq 24.003 \\
\frac{24.9-z}{3.9} ; 24.003 \leq z \leq 24.9 \\
0 ; z>24.9
\end{array}\right.
$$

d. Defuzzifikasi

Tahap terakhir dari perhitungan fuzzy ini adalah defuzzifikasi. Pada tahap ini grafik daerah defuzzifikasi akan dibagi sesuai dengan persamaan hasil komposisi aturan dan kemudian akan dihitung setiap momen dan luas daerahnya. Berikut adalah gambar grafik daerah defuzzifikasi pada Gambar 2.

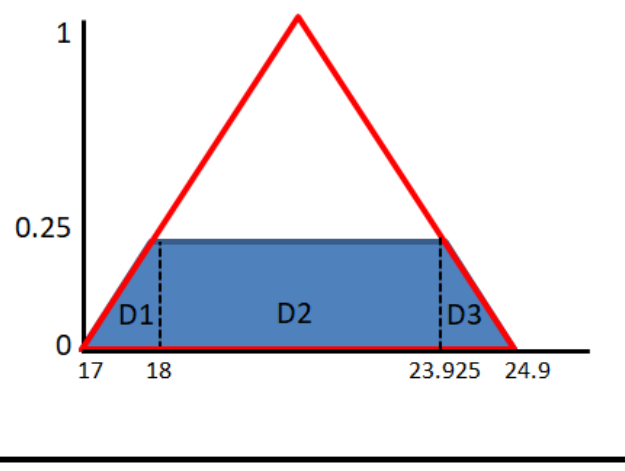

Gambar 2. Grafik Pembagian Daerah Defuzzifikasi Variabel BMI

i. Penentuan Momen Untuk Setiap Daerah

- Momen-1

$$
\begin{aligned}
M 1=\int_{17}^{18}\left(\frac{z-17}{4}\right) z d z & \\
& =\int_{17}^{18} \frac{2 z^{3}-51 z^{2}}{24}+\mathrm{C} \\
& =2,083
\end{aligned}
$$

- Momen-2

- Momen-3

$$
M 2=\int_{18}^{23.925} 0.25 z d z=31
$$

$$
M 3=\int_{23.925}^{24.9}\left(\frac{24.9-z}{3.9}\right) z d z=2.95
$$

ii. Penentuan Luas Untuk Setiap Daerah

- $\quad$ Luas D1

$$
D 1=\frac{(18-17) * 0.25}{2}=0.125
$$

- $\quad$ Luas D2

$$
D 2=(23.925-18) * 0.25=1.48
$$

- $\quad$ Luas D3

$$
D 3=\frac{(24.9-23.925) * 0.25}{2}=0.122
$$

Maka, untuk hasil titik pusat atau defuzzifikasi adalah:

$$
\begin{aligned}
& z=\frac{(M 1+M 2+M 3)}{(D 1+D 2+D 3)} \\
& z=\frac{(2,083+31+2,95)}{(0.125+1.48+0.122)} \\
& z=\frac{36.033}{1.73}=20,828 \approx 20.8
\end{aligned}
$$


Jadi, nilai BMI yang diperoleh adalah 20,8. Nilai BMI ini akan digunakan untuk perhitungan selanjutnya pada perhitungan kalori

\section{Perhitungan fuzzy penentuan nilai BMR}

I. Penentuan derajat keanggotaan masingmasing himpunan pada variabel (Fuzzifikasi)

Tabel himpunan fuzzy variabel BMI, umur, aktifitas dan kalori badan dapat dilihat pada Tabel 2.

Tabel 2. Himpunan Fuzzy Variabel BMI, Umur, Aktifitas dan Kalori

\begin{tabular}{|l|l|l|}
\hline \multirow{4}{*}{ Variabel } & Himpunan & Domain \\
\hline \multirow{4}{*}{ BMI } & Underweight & {$[10,19.9]$} \\
\cline { 2 - 3 } & Normal & {$[17,24.9]$} \\
\cline { 2 - 3 } & Overweight & {$[23,29.9]$} \\
\cline { 2 - 3 } & Obesitas & {$[28,35]$} \\
\hline \multirow{5}{*}{ Aktifitas } & Muda & {$[18,25]$} \\
\cline { 2 - 3 } & Dewasa Awal & {$[23,35]$} \\
\cline { 2 - 3 } & Dewasa Akhir & {$[30,65]$} \\
\cline { 2 - 3 } & Lansia & {$[60,80]$} \\
\hline & Sangat Ringan & {$[0,2]$} \\
\cline { 2 - 3 } & Ringan & {$[1,3]$} \\
\cline { 2 - 3 } & Sedang & {$[2,6]$} \\
\cline { 2 - 3 } & Berat & {$[5,7]$} \\
\cline { 2 - 3 } & Sangat Berat & {$[6,8]$} \\
\hline \multirow{4}{*}{ Kalori } & Sedikit & {$[800,1400]$} \\
\cline { 2 - 3 } & Sedang & {$[1200,2000]$} \\
\cline { 2 - 3 } & Banyak & {$[1900,2300]$} \\
\cline { 2 - 3 } & Sangat Banyak & {$[2200,2400]$} \\
\hline
\end{tabular}

f. Variabel BMI

Nilai variabel yang diketahui adalah 20,8. Maka derajat keanggotaan yang dihitung hanya pada himpunan NORMAL. Berikut adalah perhitungan derajat keanggotaan pada himpunan NORMAL pada persamaan 7 .

$\mu \operatorname{Normal}(20,8)=\frac{(20,8-17)}{(21-17)}=\frac{3,8}{4}=0.95$

Maka nilai derajat keanggotaan pada semua himpunan adalah sebagai berikut:

$$
\begin{gathered}
\mu \text { Underweight }(20.8)=0 \\
\mu \text { Normal }(20.8)=0.95 \\
\mu \text { Overweight }(20)=0 \\
\mu \text { Obesitas }(20)=0
\end{gathered}
$$

g. Variabel umur

Nilai variabel yang diketahui adalah 20 .

Maka derajat keanggotaan yang dihitung hanya pada himpunan REMAJA. Berikut adalah perhitungan derajat keanggotaan pada himpunan REMAJA pada persamaan (8).

$\mu \operatorname{Remaja}(20)=\frac{(25-20)}{(25-18)}=\frac{5}{7}=0.7$

Maka nilai derajat keanggotaan pada semua himpunan adalah sebagai berikut:

$$
\begin{gathered}
\mu \text { Remaja }(20)=0.7 \\
\mu \text { DewasaAwal }(20)=0 \\
\mu \text { DewasaAkhir }(20)=0 \\
\mu \operatorname{Lansia}(20)=0
\end{gathered}
$$

h. Variabel aktifitas

Pada nilai variabel himpunan fuzzy aktivitas, jika tingkat aktivitas yang diketahui adalah olahraga 2 kali seminggu, berdasarkan pada Tabel 3.3, maka nilai variabel Aktivitas $=2$. Himpunan fuzzy yang mencakupi untuk nilai variabel $=2$ adalah SANGAT RINGAN, RINGAN, dan NORMAL.

- Himpunan Sangat Ringan

$$
\mu \text { SangatRingan }(2)=\frac{(2-2)}{(2-0)}=\frac{0}{0}=0
$$

- Himpunan Ringan

$$
\mu \operatorname{Ringan}(2)=\frac{(2-1)}{(2-1)}=\frac{1}{1}=1
$$

- Himpunan Sedang

$$
\mu \operatorname{Sedang}(2)=\frac{(4-2)}{(4-2)}=\frac{0}{0}=0
$$

Dengan demikian nilai derajat keanggotaan dari masing-masing himpunan yang didapatkan adalah sebagai berikut:

$$
\begin{gathered}
\mu \text { SangatRingan }(2)=0 \\
\mu \text { Ringan }(2)=1 \\
\mu \text { Sedang }(2)=0
\end{gathered}
$$




$$
\begin{gathered}
\mu \text { Berat }(2)=0 \\
\mu \text { SangatBerat }(2)=0
\end{gathered}
$$

i. Variabel jenis kelamin

Untuk himpunan fuzzy jenis kelamin, variabel jenis kelamin yang diketahui adalah LAKI-LAKI. jika jenis kelamin yang diketahui adalah LAKI-LAKI, maka nilai variabelnya adalah 1 . maka nilai derajat keanggotaan untuk variabel Jenis Kelamin adalah:

$$
\begin{gathered}
\mu \operatorname{LakiLaki}(1)=1 \\
\mu \operatorname{Perempuan}(1)=0
\end{gathered}
$$

II. Penentuan nilai aplikasi fungsi implikasi Aturan fungsi implikasi yang digunakan adalah aturan untuk jenis kelamin Laki-Laki. Berdasarkan derajat keanggotaan yang telah dihitung, maka aturan fungsi yang diambil adalah sebagai berikut:

[R22] IF jk = LAKI-LAKI \& bmi $=$ NORMAL \& umUr $=$ REMAJA \& aktivitas $=$ RINGAN THEN kalori $=$ SEDANG.

$$
\begin{aligned}
& \alpha-\text { predikat } 1=\mu j k L a k i L a k i \cap \\
& \text { bmiNormal } \cap \text { umurRemaja } \cap \\
& \text { aktivitasRingan } \\
& =\min \left(\begin{array}{c}
\mu j k L a k i L a k i(1), \text { bmiNormal }(20,8), \\
\text { umurRemaja }(20), \\
\text { aktivitasRingan }(2)
\end{array}\right) \\
& =\min (1 ; 0.95 ; 0.7 ; 1)=0.7
\end{aligned}
$$

[R23] IF jk $=$ LAKI-LAKI \& bmi $=$ NORMAL \& umUr $=$ REMAJA \& aktivitas $=$ SEDANG THEN kalori $=$ BANYAK.

$$
\alpha-\text { predikat } 2=\mu j k \text { LakiLaki } \cap
$$

bmiNormal $\cap$ umurRemaja $\cap$

aktivitasNormal

$$
\begin{aligned}
& =\min \left(\begin{array}{c}
\mu j k L a k i L a k i(1), \text { bmiNormal }(20,8) \\
, \text { umurRemaja }(20), \\
\text { aktivitasSedang }(2)
\end{array}\right) \\
& =\min (1 ; 0.7 ; 0.95 ; 0)=0
\end{aligned}
$$

[R42] IF $j k=$ LAKI-LAKI \& bmi $=$ OVERWEIGHT \& umUr $=$ REMAJA \& aktivitas $=$ RINGAN THEN kalori $=$ SEDANG. $\alpha-$ predikat $3=\mu j k$ LakiLaki $\cap$

bmiOverweight $\cap$ umurRemaja $\cap$

aktivitasRingan

$$
\begin{aligned}
& =\min \left(\begin{array}{c}
\mu j k \operatorname{lakiLaki}(1), \\
\text { bmiOverweight }(20,8) \\
\text { umurRemaja }(20), \\
\text { aktivitasRingan }(2)
\end{array}\right) \\
& =\min (1 ; 0 ; 0.7 ; 1)=0
\end{aligned}
$$

[R43] IF jk = LAKI-LAKI \& bmi = OVERWEIGHT \& umUr = REMAJA \& aktivitas $=$ SEDANG THEN kalori $=$ BANYAK.

$$
\alpha-\text { predikat } 4=\mu j k \text { LakiLaki } \cap
$$

bmiOverweight $\cap$ umurRemaja $\cap$

aktivitasSedang

$$
=\min \left(\begin{array}{c}
\mu j k \operatorname{LakiLaki}(1), \\
\text { bmiOverweight }(20,8) \\
\text { umurRemaja }(20), \\
\text { aktivitasSedang }(2)
\end{array}\right)
$$$$
=\min (1 ; 0 ; 0.7 ; 0)=0
$$

III. Komposisi Aturan

Berdasarkan hasil dari aplikasi fungsi implikasi (aturan) didapatkan nilai 0.7 adalah nilai yang tertinggi dan nilai 0 adalah yang terendah. Berikut adalah persamaan komposisi aturan pada persamaan 8

$$
\begin{aligned}
\mu s f(x)= & \operatorname{maks}\{(\mu \text { kaloriSedang }(0.7), \\
& \mu \text { kaloriBanyak }(0)\} \\
= & \operatorname{maks}(0.7 ; 0)=0.7
\end{aligned}
$$

Karena pada nilai implikasi diatas hanya variabel kalori SEDANG yang memotong garis, maka untuk variabel kalori BANYAK tidak perlu dihitung karena nilainya 0 . Berikut adalah grafik dari himpunan kalori SEDANG untuk nilai derajat keanggotaan $=0,7$ pada Gambar 3. 


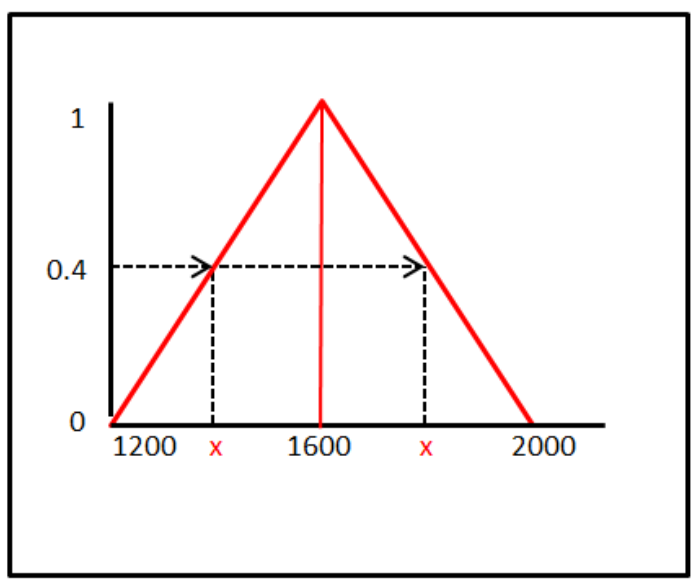

Gambar 3. Grafik Variabel Kalori Himpunan SEDANG pada Komposisi Aturan

Berikut adalah nilai $\mathrm{x}$ pada daerah implikasi variabel kalori SEDANG:

$$
\begin{gathered}
0.7=\frac{x-1200}{1600-1200} \\
x=1200+280 \\
x=1480 \\
\text { atau } \\
0.7=\frac{2000-x}{2000-1600} \\
x=2000-280=1720
\end{gathered}
$$

IV. Defuzzifikasi

Pada defuzzifikasi ini grafik himpunan yang digunakan adalah himpunan SEDANG. Berikut adalah gambar dari grafik untuk perhitungan defuzzifikasi yang telah dibagi berdasarkan nilai $\mathrm{x}$ pada komposisi aturan pada Gambar 4.

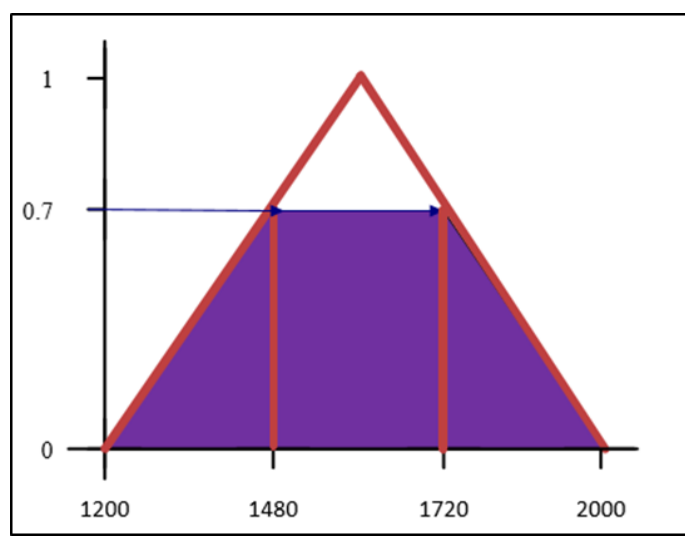

Gambar 4. Grafik Pembagian Daerah Defuzzifikasi Variabel Kalori Himpunan Sedang a. Penentuan Momen Untuk Setiap Daerah

- $\quad$ Momen-1

$$
\begin{gathered}
M 1=\int_{1200}^{1480}\left(\frac{x-1200}{1600-1200}\right) x d x \\
=135.893,3
\end{gathered}
$$

- $\quad$ Momen-2

$$
M 2=\int_{1480}^{1720} 0.7 x d x=531.440
$$

- $\quad$ Momen-3

$$
\begin{gathered}
M 3=\int_{1720}^{2000}\left(\frac{2000-x}{2000-1600}\right) x d x \\
=177.706,6
\end{gathered}
$$

b. Penentuan Luas Untuk Setiap Daerah

- $\quad$ Luas D1

$$
D 1=\frac{(1480-1200) * 0.7}{2}=98
$$

- $\quad$ Luas D2

$$
D 2=(1720-1480) * 0.7=168
$$

- $\quad$ Luas D3

$$
D 3=\frac{(2000-1720) * 0.7}{2}=98
$$

Maka, untuk hasil titik pusat atau defuzzifikasi adalah:

$$
\begin{aligned}
& z=\frac{(M 1+M 2+M 3)}{(D 1+D 2+D 3)} \\
& =\frac{(135.893,3+531.440+177.706,6)}{(98+168+98)} \\
& z=\frac{845039.9}{256364}=2321.538 \approx 2321
\end{aligned}
$$

Dengan demikian hasil akhir nilai BMI dan Kalori yang dibutuhkan berdasarkan variabel yang diketahui adalah 20,8 dan 2321 kkal.

\section{IMPLEMENTASI APLIKASI}

Langkah-langkah implementasi pada aplikasi SmartDiet menggunakan Android adalah sebagai berikut. 
a. Halaman Menu Utama

Untuk memulai menghitung BMI dan BMR, dapat menekan tombol 'Mulai' pada menu utama. Tampilan menu utama dapat dilihat pada Gambar 5.

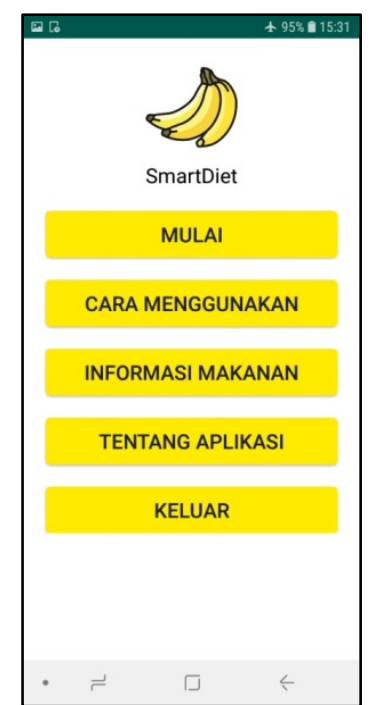

Gambar 5. Halaman Menu Utama

b. Halaman Input Berat Badan, Tinggi Badan dan Umur

Selanjutnya akan ditampilkan halaman untuk menginput berat badan, tinggi badan dan umur. Tampilan halaman tersebut dapat dilihat pada Gambar 6.

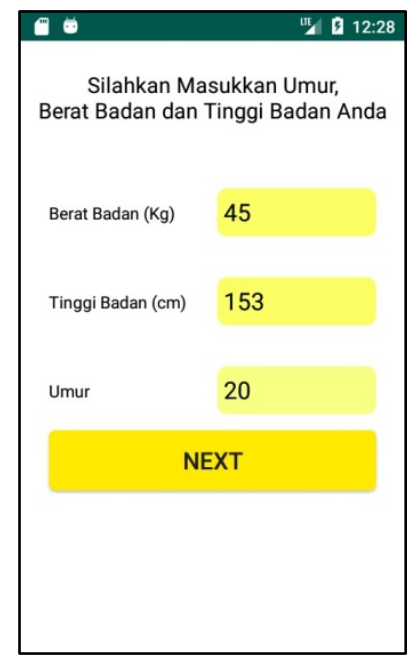

Gambar 6. Halaman Input Berat Badan, Tinggi Badan dan Umur

c. Halaman Pilihan Tingkat Aktifitas

Selanjutnya akan ditampilkan halaman untuk menginput tingkat aktifitas. Tampilan halaman pilihan tingkat aktifitas dapat dilihat pada Gambar 7.

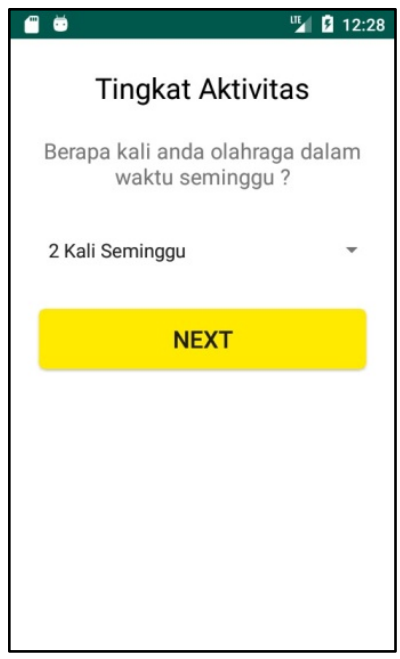

Gambar 7. Halaman Tingkat Aktifitas

d. Halaman Pilihan Jenis Kelamin

Selanjutnya akan ditampilkan halaman untuk memilih jenis kelamin. Tampilan halaman pilihan jenis kelamin dapat dilihat pada Gambar 8.

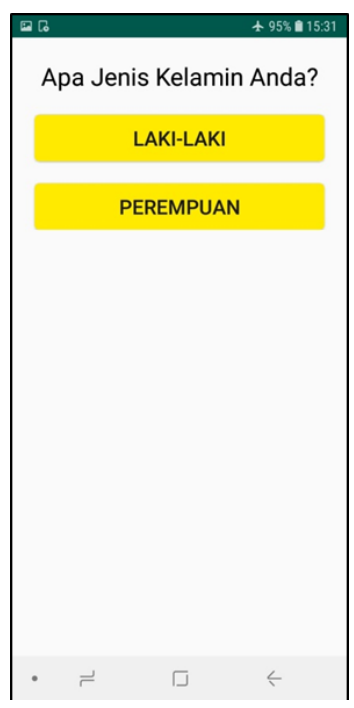

Gambar 8. Halaman Pilihan Jenis

Kelamin

\section{e. Hasil Akhir}

Setelah semua data dimasukkan, hasil nilai BMI dan BMR dapat ditampilkan pada halaman selanjutnya. Tampilan halaman hasil akhir dapat dilihat pada Gambar 9. 


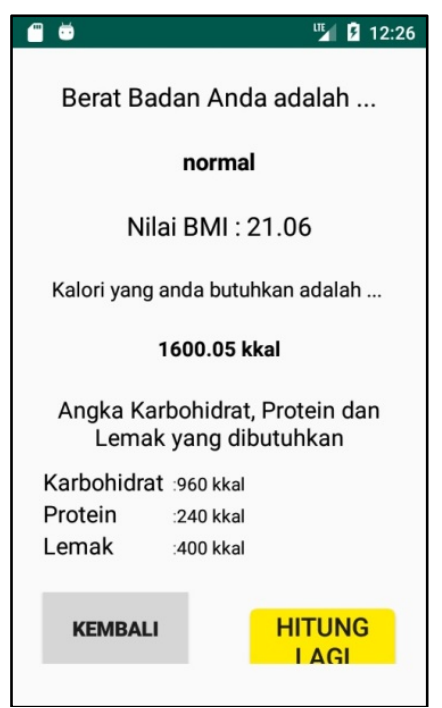

Gambar 9. Halaman Hasil Akhir

Dari Gambar 9 dapat diketahui berat badan $45 \mathrm{~kg}$, tinggi badan $153 \mathrm{~cm}$, umur 20 tahun, jenis kelamin laki-laki dan tingkat aktifitas 2 kali seminggu mempunyai nilai BMI 21.06 dan nilai BMR sebanyak 1600.05 kalori. Berikut adalah tabel hasil perbandingan output manual dengan aplikasi pada Tabel 3.

Tabel 3. Perbandingan Output Manual dengan Aplikasi

\begin{tabular}{|c|c|c|c|c|c|c|c|c|c|c|}
\hline \multirow{2}{*}{ No. } & \multicolumn{4}{|c|}{ Variabel Input } & \multicolumn{2}{c|}{ Output dengan Manual } & \multicolumn{2}{c|}{ Output dengan Sistem } & Tingkat \\
\cline { 2 - 11 } & $\begin{array}{c}\text { Berat } \\
\text { Badan }\end{array}$ & $\begin{array}{c}\text { Tinggi } \\
\text { Badan }\end{array}$ & Umur & $\begin{array}{c}\text { Jenis } \\
\text { Kelamin }\end{array}$ & $\begin{array}{c}\text { Tingkat } \\
\text { Aktivitas }\end{array}$ & BMI & Kalori & BMI & Kalori & \\
\hline 1. & 47 & 160 & 21 & Perempuan & 2 & 18.4 & 1781.45 & 18 & 1600 & $93.8 \%$ \\
\hline 2. & 54 & 170 & 22 & Perempuan & 1 & 18.7 & 1892 & 15 & 1672 & $84.25 \%$ \\
\hline 3. & 60 & 175 & 35 & Laki-Laki & 3 & 19.6 & 2326 & 21 & 2100 & $91.75 \%$ \\
\hline 4. & 75 & 165 & 27 & Laki-Laki & 0 & 27.5 & 2081.88 & 26.5 & 2100 & $93.25 \%$ \\
\hline 5. & 60 & 160 & 54 & Perempuan & 0 & 23.4 & 1518.63 & 26.5 & 1600 & $91.6 \%$ \\
\hline 6. & 66 & 163 & 33 & Perempuan & 2 & 24.8 & 1962 & 28 & 1810 & $90.35 \%$ \\
\hline 7. & 52 & 165 & 19 & Laki-Laki & 3 & 19.1 & 2285 & 17 & 2100 & $86 \%$ \\
\hline 8. & 72 & 177 & 45 & Laki-Laki & 4 & 23 & 2528.67 & 21 & 2100 & $87.15 \%$ \\
\hline 9. & 62 & 158 & 30 & Perempuan & 1 & 24.8 & 1916.34 & 26.5 & 1600 & $88.5 \%$ \\
\hline
\end{tabular}




\section{SIMPULAN DAN SARAN}

Adapun kesimpulan yang didapat dari penelitian ini adalah sebagai berikut:

1. Penggunaan logika fuzzy dengan metode Mamdani pada aplikasi SmartDiet mampu menentukan nilai BMI dan angka kalori.

2. Pada perhitungan penentuan nilai BMI, variabel inputan yang diperlukan adalah tinggi badan dan berat badan. Sedangkan untuk penentuan nilai kalori, variabel inputan yang diperlukan adalah nilai BMI, umur, jenis kelamin dan tingkat aktivitas.

3. Tahap dari perhitungan penentuan nilai BMI dan kalori terdiri dari empat tahap yaitu penentuan himpunan fuzzy, aplikasi fungsi implikasi, komposisi aturan dan defuzzifikasi.

4. Pada hasil akhir perhitungan nilai BMI dan kalori pada aplikasi SmartDiet akan ditampilkan nilai BMI sesuai dengan kategorinya, angka kebutuhan kalori agar mencapai berat badan ideal serta pembagian angka jenis gizi (karbohidrat, protein dan lemak).

5. Hasil uji coba pada penelitian ini mendapatkan hasil perhitungan dengan nilai keakuratan sebanyak $89.62 \%$ dan nilai error sebanyak $10.38 \%$.

\section{DAFTAR PUSTAKA}

[1] Jati Kusuma, B dan T. Pinandita, Rancang Bangun Aplikasi Mobile Perhitungan Indeks Massa Tubuh dan Berat Badan Ideal (A Design of Mobile Application to Measure Body Mass Index and an Ideal Weight), Jurnal Juita. 1(4) (2011), pp. 157168.

[2] Ariati, N.N., Gizi Dan Produktifitas Kerja, J. Skala Husada. 10(2) (2013), pp. 214-218.
[3] Naluri, P.N.M.S, Dengan Komposisi

Tubuh Pada Anak Obesitas, Artik. Ilm Universitas Diponegoro. (2011).

[4] N. Febriany, F. Agustina, DAN R. Marwati, Aplikasi Metode Fuzzy Mamdani Dalam Penentuan Status Gizi Dan Menggunakan Software Matlab, J. EurekaMatika. 5(1) (2017), pp. 84-96.

[5] R. B. Ginting, Analisis Fungsi Implikasi Max-Min dan Max-Prod Dalam Pengambilan Keputusan, Creat. Inf. Technol. J. 1(2) (2015), p. 128.

[6] Wiguna, M.R.Y, Hanny H., Sistem Berbasis Aturan Menggunakan Logika Fuzzy Tsukamoto Untuk Prediksi Jumlah Produksi Roti Pada CV. Gendis Bakery, Jurnal Universitas Dian Nuswantoro, (2015).

[7] Hasanah, S.N., N.I. Widiastuti, Representasi Emosi Menggunakan Logika Fuzzy Pada Permainan Bonny's Tooth Booth, Jurnal Ilmiah Komputer dan Informatika ( KOMPUTA ). 3(2) (2014), pp. 68-72.

[8] S. Arifin, M. A. Muslim, dan S.

Sugiman, Implementasi Logika Fuzzy Mamdani untuk Mendeteksi Kerentanan Daerah Banjir di Semarang Utara, Sci. J. Informatics. 2(2) (2016), pp. 179.

[9] A. R. Wardani, Y. N. Nasution, dan F. D. T. Amijaya, Aplikasi Logika Fuzzy Dalam Mengoptimalkan Produksi Minyak Kelapa Sawit Di PT. Waru Kaltim Plantation Menggunakan Metode Mamdani, Jurnal Informatika Mulawarman.12(2) (2017), pp. 94.

[10] E. S. Puspita dan L. Yulianti, Perancangan Sistem Peramalan Cuaca Berbasis Logika Fuzzy, J. Media Infotama. 12(1) (2016), pp. 1-10. 